\title{
The Effect of Talking Story Books on Saudi Young EFL Learners' Reading Comprehension
}

\author{
Hashem Ahmed Alsamadani ${ }^{1}$ \\ ${ }^{1}$ College of Education, Um-Alqura University, Saudi Arabia \\ Correspondence: Hashem Ahmed Alsamadani, College of Education, Um-Alqura University, Saudi Arabia. \\ E-mail: hmazawid@gmail.com
}

$\begin{aligned} & \text { Received: March 13, } 2017 \\ & \text { Accepted: April 25, } 2017 \quad \text { Online Published: April 27, } 2017 \\ & \text { doi: 10.5539/elt.v10n5p204 }\end{aligned}$ URL: http://doi.org/10.5539/elt.v10n5p204

\begin{abstract}
The current research study investigated the effects of talking story books on Saudi young EFL learners' reading comprehension skills. A sample of Saudi-young-EFL learners were randomly selected and divided into two groups: an experimental group (40 students) and a control group (39 students). Students of both groups took a pre reading comprehension test at the mid of the 2016 academic year. The researcher used the talking story books when teaching the experimental group for four weeks whereas the students in the control group were taught without the use of talking story books. After four weeks of instruction, both groups completed the same reading comprehension test again. Measures of the means, standard deviations, and MANCOVA were used to determine the differences between the two groups. The study revealed that students who attended reading classes using talking story books outperformed their control group counterparts in many reading-based skills. This is indicative of the positive effects of talking story books on EFL young learners reading comprehension skills.
\end{abstract}

Keywords: talking story books, reading, comprehension, skills, read-aloud activities

\section{Introduction}

Pedagogically, not a single language skill can be taught or learnt solely no matter what and how. Simply put, writing can be typically improved through reading and speaking can be enhanced by listening activities. Everyone admits that in as much as language skills overlap, teachers and learners of English as a Foreign Language (EFL) cannot draw a line between each two skills; EFL learning can be possibly optimized when two skills or more are integrated with each other or else learners feel much disinterested. More interestingly, reading aloud is not the only key to improve reading skills; it opens wide opportunities for EFL learners to better enhance other language skills. Reading per se generates a whole host of microscopic skills including writing, spelling, grammar, punctuations and word-choice. Furthermore, reading aloud stimulates requisite EFL learners' skills that otherwise pass unnoticed, such as stress, intonation, accent, rhythm, phonic realization, pronunciation, assimilation, word-choice and other microscopic skills (Zimmerman, 2010; Du, 2016; Kalmane, 2012; Al-Mahrooqi \& Roscoe, 2014). Talking story books can be effective in shadowing speaking skills: EFL learners can bubble chunks of words while listening which improves their speaking ability (Hamada, 2017). Epistemologically, reading has clear impact on the acquisition of other language skills; EFL writing is improved or should be improved through exposing learners to extensive reading (Kirin, 2010; Muslim, 2014; Mermelstein, 2015; Al- Mansour and Al-Shorman, 2014). In the same vein, research studies also reveal that talking books enhance EFL learner's speaking and pronunciation skills at different levels (Saka, 2015; Mart, 2012; Hamada, 2017; Hall, 2016).

Using talking story books for EFL learners to boost their reading comprehension skills can be justified by various reasons, among which is to make it a departure point from the traditional methods of teaching reading; EFL children do not need to be overloaded with too much non-verbal activities (Soler \& Openshaw, 2006). Increasingly but not sufficiently, talking story books would possibly invade the print-based reading materials. Learners, at their ease and pace, can get engaged any time with zero-level fear of mispronunciation. They would also feel much interested not in what is presented, but in how it is presented rivetingly and spellbindingly; "while we recognise the potential benefits of talking books over traditional print-based material, we are aware of the need for multimedia textsfor readers of all ages" (Collins et al., 2002).

EFL learners of countries where reading is taught only through written skills are reported of displaying weak 
performance in speaking and listening as is the case in Saudi Arabia, Iran, Japan, Russia (Al-Ma'shy, 2011; Zolfagharkhani \& Kowsary, 2013; Stroh, 2012; Seo, 2014; Al-Mansour \& Al-Shorman, 2014). Reading comprehension difficulties encountered by EFL Arab learners of different levels are also reported on by several research studies, such as Mourtaga, 2006; O'Sullivan, 2004; Negmeldin and Hala, 2011a; Ahmed and Abouabdelkader, 2016; Bailey and Damerow, 2014. The current study adds to the bulk of research on the use of talking-story books / reading aloud in EFL setting and how it should be used in line with silent reading to make up for the poor exposure to native English.

\subsection{Literature Review}

In learning settings where English is used as a first language, the effectiveness and significance of read-aloud activities are assigned a number-one priority; while, in EFL settings talking story books are still silhouetted and backgrounded. EFL young learners can better enhance their listening skills through read-aloud activities (Isbell et al., 2004; Ellis, 1997; Alna, 1999; Baskin, 2016). One cogent reason that explains why talking story books are increasingly becoming the pleasant flavour in teaching reading skills in an EFL setting is the dire need to have native teachers of English; non-native teachers of English often graduate from universities with poor exposure to native English which can negatively affect their students' listening and speaking skills. Hillman (1975) states that providing EFL learners with read-aloud materials help them hear the vocabulary in context with immaculate pronunciation. In a research study conducted on children of 4th, 5th and 6th graders, McCormick (1977) found that the children who were provided with read-aloud materials and activities for several months gained much improvement in reading comprehension, vocabulary, word-choice and pronunciation. In the same vein, Elley (1991) emphasizes the importance of exposing children to a great deal of high-quality of read-aloud and storytelling materials such as talking story books. This makes children free from the constraint of structure, grammar and vocabulary and get engaged in natural-flowing English contexts. Elley also argues that read-aloud activities help children acquire extensive vocabulary and proper pronunciation. Furthermore, Williamson (1988) argues that English teachers are highly recommended to increase the read-aloud materials and in-class activities, as innovative storytelling-like teaching method creates a robust engagement for learners, provides a conducive feel of how English is used, and enhances the fun factor, as well.

Exposing learners in general and EFL learners in particular to real-life situations carried out by native speakers, which in turn enhances the learner's spontaneous ability to comprehend and respond (Zaytoun, 1988). In addition, Zaytoun recommends that teachers should use natural read-aloud stories that add natural exposure to English. The learners gain more idioms, collocations, pronunciations, phrases and many other microscopic skills. In an extensive research study conducted in 32 countries on 210.000 learners ( 9 years and 14 years) over two years (1990-1991), Warwick reveals fantastic results of the use of read-aloud activities. The findings reveal that due to the extensive frequency of read-aloud activities carried out by the teachers, the learners' scores were high. In as much as Finland, United States, Sweden and France followed this innovative method, they were top four countries in terms of higher performance of reading comprehension skills.

The read-aloud teaching method is also effective for pre-school and 1st graders. The research study conducted by Vivas (1996) revealed that children improved their listening skills as they were exposed to read-aloud stories which in turn enhanced their reading comprehension skills. Similarly, Trelease (1994) found that children who learnt English through read-aloud stories, talking story books and storytelling activities performed much better than the children who were not exposed to such activities: the first student group turned learning into fun while the second group felt like it was something boring and a chore-like assignment. In a 75-EFL student research study on the effects of read-aloud stories, Amer (1997) found that the experimental group performed much better than the control group on multiple-choice questions and a story frame test. Even at the kindergarten level, McCarthy et al. (2001) found that stories read aloud helped 1st, 2nd and 3rd graders to improve their background knowledge in building vocabulary, pronouncing words and listening to natural-flowing English. The learners were also found to have developed their reading habits motivated by a fun factor. In 'Project Story Boost' which was based on read-aloud activities for several weeks, Wood and Salvetti (2001) reveal that children who participated in this project enhanced their vocabulary development and impressively participated in the small in-class discussions as well as reading skills. Morgan (2002) found that reading a story aloud for learners was better than independent story-reading. In addition, in a 10-week study on 53 th and 6th graders in the kindergarten, Queini et al. (2008) reveal that children improved their comprehension skills and vocabulary performance.

Al-Mansour and Al-Shorman (2010) carried out a research study on the effect of teacher's storytelling aloud on the reading comprehension of Saudi elementary stage students. The results go in line with the previous studies. Read-aloud materials positively helped learners' reading comprehension skills. It also built interest in the reading 
process, stimulated discussion, and enhanced self-confidence in the participants (Al-Mansour \& Al-Shorman, 2010).

Seo (2014) poses an interesting question in her research study: Does reading aloud improve foreign language learners' speaking ability? The results of the study reveal that children's speaking ability improved through read-aloud robust engagement; "even though their early stage speaking level was not the same, reading aloud resulted in progress in students' speaking level and their usage of grammar. By reading aloud repeatedly, students were able to get used to the unique sounds of Japanese pronunciation and produce more natural sentences. This also boosted their confidence in speaking Japanese. Considering that the practice had been done only for 5 minutes daily in class as a warm-up activity, the positive effect is particularly promising" (Seo, 2014). Stroh (2012) also carried out a research study on the effect of repeated read-aloud stories on the Russian language learners'speaking fluency. Stroh reveals that the practice of reading stories aloud to learners improved some but not all the speaking skills. Zolfagharkhani and Kowsary (2013) investigated the relationship between reading aloud strategies and comprehension among the Iranian EFL learners in pre-intermediate levels. The results show that learners whose proficiency in English is basic have a better understanding of the teacher's read-aloud scenario than in a silent reading scenario. Saka (2015) investigates the effectiveness of using audiobooks on EFL learner's pronunciation at different proficiency levels. She concludes that audiobooks should be integrated in the education curricula and more audiobooks should be published with state-of-the-art interactive features to create more robust engagement for EFL learners.

\subsection{Problem of the Study}

It has been increasingly observed in Saudi Arabia that audiobooks, talking story books and read-aloud activities are glaringly overshadowed by other non-verbal skills such as grammar, spelling and writing across all the stages. Although read-aloud materials are occasionally used in the kindergarten and the elementary stage to add a fun factor to learners, they disappear through the next stages. With talking story books downright disregarded, Saudi EFL young learners are always reported by their teachers as being unable to read aloud or understand the materials if read aloud. The lack of such a requisite skill takes them away from natural scenarios and enables them to master only non-verbal skills which is not what language communication is all about. Teaching methodologists, pedagogists and EFL education experts also notice that Saudi EFL young and adult learners obtain low scores in reading and listening examinations. To tackle such a gap, researchers, teachers and even parents suggest using talking story books, storytelling and audiobooks.

\subsection{Significance of the Study}

Read-aloud activities and talking story books for EFL young learners makes English classes spellbinding and riveting. Using such tools can potentially enhance language skills in general and improve reading skills in particular (Saka, 2015; Zolfagharkhani \& Kowsary, 2013; Stroh, 2012; Seo, 2014; Al-Ma'shy, 2011; Mart, 2012; Kaderavek \& Justice, 2002). In addition, read-aloud tools and talking story books are a source of vicarious entertainment for EFL young learners that make the class more enthralling and help them retain the components for longer time (Haven, 2000; Alna, 1999; Mallan, 1997; Cohen \& Cowen, 2009). Although the role of read-aloud activities play a vital role in EFL classes, they are not given such a considerable significance by teachers in application, and more is required to be done in EFL settings (Collins et al., 2002; Hamada, 2017; Hall, 2016; Möller, 2015). Of course, head teachers, ministry deputies and other education experts would feel reluctant to implement such innovative ideas of using talking story books in EFL setting for young learners unless proved effective in practice (Saka, 2015). In the same vein, Gallets (2005) argues that the reason why storytelling, audiobooks and talking story books are of less popularity can be due to their qualitative or anecdotal benefit. The current research study aims at investigating the effects of using talking story books on Saudi young EFL learners' reading comprehension skills in the elementary stage. The research study is attempting to open up a pristine education window through which Saudi young EFL learners can improve their readings skills not only through traditional methods. But more robustly, through a semi-independent heuristic method. Potentially, it is hoped that the outcomes will be but not limited to the following:

1) To methodologically upgrade the way EFL teachers teach Saudi young learners reading skills;

2) To help EFL teachers integrate different abilities within reading skills in order to enhance learners' memory reception, retention and interaction;

3) To open up other research studies that can further change EFL teaching settings in Saudi Arabia;

\subsection{Objective of the Study}

In light of the importance of upgrading school curricula for EFL learners, the present research study attempts to 
investigate the effects of talking story books on the Saudi young EFL learners reading comprehension skills. Reading comprehension is defined and measured in this study as the students':

- Reading-Based retelling ability.

- Understanding of talking-story-books.

- Reading-Based spelling skills.

- $\quad$ Reading-Based phonics skills.

It is hoped that talking story books will create a conducive and enthralling EFL learning environment that engages learners and stimulates EFL teachers to implement this method in their everyday classes. It is also hoped that teachers in elementary schools will make reading this study a departure point to embrace more innovative teaching methods.

\subsection{Questions of the Study}

The main research question of this study was as follows: What is the effect of using talking story books on Saudi young EFL learners reading comprehension? This question was divided into the following four sub-questions:

1) What is the effect of using talking story books on Saudi young EFL learners' reading-based retelling skills?

2) What is the effect of using talking story books on Saudi young EFL learners' understanding of talking story books?

3) What is the effect of using talking story books on Saudi young EFL learners' reading-based spelling skills?

4) What is the effect of using talking story books on Saudi young EFL learners' reading-based phonics skills?

\section{Method}

\subsection{Participants}

The population of the study was the entire elementary students in Jeddah, Saudi Arabia in the academic year 2015-2016. A total of 79 EFL male Saudi young students were randomly selected from a public elementary school - Prince Bandar elementary school- in Jeddah, Saudi Arabia. The experimental group consisted of 40 students while the control group was 39 students. All the participants had received their English tuition over the past two years in the same school. The participants were 6th graders, whose ages ranged from 11 to 12 . Because some participants might have been enrolled in kindergarten or received some private classes at home, a reading comprehension test was administered prior to the experiment to ensure that the sample was homogeneous. The experiment was then conducted for four weeks; each week a new talking story book was used along with its assessment activities.

\subsection{Instruments}

The study used a sample of talking story books selected from the collection of Lady Bird stories Level 3 designed especially for EFL young learners: Rapunzel, Jack and the Beanstalk, Little Red Riding Hood and the Wolf and the Seven Little Kids. The talking story books represented different themes and were played at a child-like pace and tone to engage the participants. Each participant was provided with a well-illustrated talking story book while the audio was played at one time for about 5 to 6 minutes. The number of words in each selected talking story book ranged from 1300 to 1600 words in a purposefully simplified English form.

The researcher also designed a pre / post-test to assess the participants' performance. This test included a short reading comprehension passage, followed by multiple choice questions based on the themes, true-false questions and WH-questions to further gauge the participants' robust engagement.

\subsubsection{Reliability of the Test}

The reliability of the reading comprehension test was measured by using the test-retest procedure. In the second week of the semester, the test was administered to a group of Saudi young learners (30 students), who were enrolled in the same school but were not included in the study sample. Two weeks later, the same test was re-administered to the same group and proved to be highly reliable: Cronbach's alpha $=.86$

\subsection{Procedures}

The research took place in the period from Nov. through Dec. 2016. Pre-test data were collected at the beginning of the semester prior to the initiation of the intervention. Post-test data collection was conducted at the end of the four weeks, i.e., after the completion of the experimental intervention. The experiment took place during the four weeks using multiple tasks. The participants were requested to listen to the talking story book played for about 4 
to 5 minutes in order to understand the story. Then they were set into a whole host of activities; each activity was designed to assess a certain component in reading comprehension skills as mapped out:

- Task One Memory-Based Understanding: the participants were requested to listen to a selected talking story book once or twice for about 5-6 minutes, paying attention to the main ideas, pronunciation, sequencing of ideas and specific word-choices.

- Task Two Reading-Based Narrative Speaking Skills: the participants were requested to re-tell the story in their own simple English words.

- Task Three In-Depth Understanding: a set of true-false questions were provided to the participants to answer, based on their understanding of the talking story book chosen.

- Task Four Phonics Reading Skills: selected words from the talking story book were given to the participants to supply the missing sound or pronounce them after replaying the talking story book.

The experimental group consisted of forty Saudi young EFL learners divided into two classes of twenty students each. While the control group consisted of thirty nine Saudi young EFL learners assigned to two classrooms. The control group was provided no talking story books over 4 weeks; the reading classes were conducted traditionally. The learners used to read the reading materials silently for 10 minutes after the teacher's model reading then they were assisted by the teacher to answer the reading comprehension questions, which assessed only the learners' understanding of the material.

Each participant of the experimental group was provided with a talking story book. The audio was played once or twice a day at the learners' pace. Then the participants were requested to do five-task activities over the week on each talking story book selected; each week they were requested to hear one along with support materials on reading comprehension. Task 1 was done on day 2 of the week: the participants were asked to pay attention to the main ideas, understand how the story ideas are sequenced logically and chronologically and which words were selected. This was meant to add a fun factor making reading such a riveting and engaging material rather than boring.

Task 2 was done on day 2 of the week: the participants were requested to retell the story after hearing once or twice. This was meant to enhance their auditory memory retention and to make reading materials a natural experience which strengthens and enriches their ability to narrate events naturally. This has heuristic links to listening and speaking based on the reading support material.

Task 3 was done on day 3: after playing the talking story book once or twice, the participants were given a set of true-false questions. This was to assess their reading comprehension, as well as auditory memory and perception skills.

Task 4 was done on day 4: after replaying the selected talking story book, selected words were given to the participants to provide the missing sounds, which was meant to improve learners' auditory discrimination of phonics and distinctive sounds such as such as [think] and [thing], [feel] and [fill], [feel] and [veal], [choose] and [shoes], [bad] and [pad], [pull] and [pole] etc.

Task 5 was done on day 5: the participants were asked to complete the narration after playing the audio for each 10-15 seconds. This was meant to assess their auditory sequencing and memory retention as it helps to remember the word-choice of the narrator. On the final day of each week - day 5 - the participants were asked to write a fitting conclusion or completion of 3-5 lines to each talking story book to enhance their based-reading imagination and prediction. To assess the performance of each group after exposing the experimental group participants to the activities of the talking story books and using traditional ways to teach reading skills to the control group participants, a post reading comprehension test was administered to the entire participants of both groups.

\section{Results and Discussion}

Before performing the main statistical test to answer the research questions, descriptive results were obtained to achieve a general understanding of the differences between the means of the two groups. 
Table 1. Means and standard deviations of pre and post-tests

\begin{tabular}{|c|c|c|c|c|c|c|c|c|c|}
\hline \multirow[t]{2}{*}{ group } & \multirow[b]{2}{*}{$\mathrm{N}$} & \multicolumn{8}{|c|}{ Pre-storyPost-storyPre-spellingPost-spellingPre-phonicsPost-phonicsPre-compPost-comp } \\
\hline & & 39 & 39 & 39 & 39 & 39 & 39 & 39 & 39 \\
\hline \multirow[t]{3}{*}{ control } & $\begin{array}{l}\text { Std. } \\
\text { Deviation }\end{array}$ & 1.81 & 1.87 & 2.31 & 1.50 & 1.89 & 1.04 & 2.41 & 2.34 \\
\hline & Mean & 11.0 & 14.8 & 11.6 & 16.3 & 12.8 & 16.5 & 12.2 & 16.9 \\
\hline & $\mathrm{N}$ & 40 & 40 & 40 & 40 & 40 & 40 & 40 & 40 \\
\hline \multirow{3}{*}{ experimental } & $1_{\text {Deviation }}^{\text {Std. }}$ & 2.16 & 2.38 & 2.64 & 2.03 & 1.50 & 1.08 & 2.36 & .985 \\
\hline & Mean & 11.7 & 22.1 & 12.7 & 23.2 & 12.1 & 23.4 & 12.9 & 24.1 \\
\hline & $\mathrm{N}$ & 79 & 79 & 79 & 79 & 79 & 79 & 79 & 79 \\
\hline \multirow[t]{2}{*}{ Total } & $\begin{array}{l}\text { Std. } \\
\text { Deviation }\end{array}$ & 2.02 & 4.22 & 2.52 & 3.92 & 1.69 & 3.66 & 2.40 & 4.00 \\
\hline & Mean & 11.32 & 18.5 & 12.12 & 19.8 & 12.15 & 20.0 & 12.52 & 20.5 \\
\hline
\end{tabular}

Table 1 shows that there were clear differences between the mean scores of the two groups at all levels. To determine the significance of these differences and to answer the research question (will learners in the experimental group achieve significantly higher scores on a test of reading comprehension than those in the control group?), a one-way multiple analysis of covariance (MANCOVA) was conducted to measure the effectiveness of the talking story books on students' reading comprehension as defined by the study:

- $\quad$ Reading-Based retelling ability.

- Understanding of talking-story-books.

- $\quad$ Reading-Based spelling skills.

- $\quad$ Reading-Based phonics skills

The independent variable was the use of talking story books when teaching reading, and the dependent variable consisted of students' scores on the above mentioned four levels. Participants' scores on the pre-test were used as covariates in this analysis.

Table 2. Tests results showing between-subjects effects

\begin{tabular}{|c|c|c|c|c|c|c|c|c|}
\hline Source & $\begin{array}{l}\text { Dependent } \\
\text { Variable }\end{array}$ & $\begin{array}{l}\text { Type III } \\
\text { Squares }\end{array}$ & Sum ofdf & $\begin{array}{l}\text { Mean } \\
\text { Square }\end{array}$ & $\bar{F}$ & Sig. & $\begin{array}{l}\text { Partial } \\
\text { Squared }\end{array}$ & $\overline{\text { Eta }}$ \\
\hline \multirow{4}{*}{ Corrected Model } & Post-story & $774.411^{\mathrm{a}}$ & 2 & 387.205 & 47.517 & .000 & .556 & \\
\hline & Post-spelling & $807.105^{\mathrm{b}}$ & 2 & 403.553 & 78.309 & .000 & .673 & \\
\hline & Post-phonics & $802.021^{\mathrm{c}}$ & 2 & 401.011 & 125.436 & .000 & .767 & \\
\hline & Post-comp & $851.053^{\mathrm{d}}$ & 2 & 425.527 & 81.130 & .000 & .681 & \\
\hline \multirow{4}{*}{ Intercept } & Post-story & 3939.513 & 1 & 3939.513 & 483.446 & .000 & .864 & \\
\hline & Post-spelling & 4567.100 & 1 & 4567.100 & 886.240 & .000 & .921 & \\
\hline & Post-phonics & 4898.171 & 1 & 4898.171 & 1532.151 & .000 & .953 & \\
\hline & Post-comp & 5111.672 & 1 & 5111.672 & 974.586 & .000 & .928 & \\
\hline \multirow{4}{*}{$\begin{array}{l}\text { group * pre-story } \\
\text { pre-spelling } * \text { pre-phonics } \\
\text { pre-comp }\end{array}$} & Post-story & 774.411 & 2 & 387.205 & 47.517 & .000 & .556 & \\
\hline & * Post-spelling & 807.105 & 2 & 403.553 & 78.309 & .000 & .673 & \\
\hline & Post-phonics & 802.021 & 2 & 401.011 & 125.436 & .000 & .767 & \\
\hline & Post-comp & 851.053 & 2 & 425.527 & 81.130 & .000 & .681 & \\
\hline Error & Post-story & 619.311 & 76 & 8.149 & & & & \\
\hline
\end{tabular}




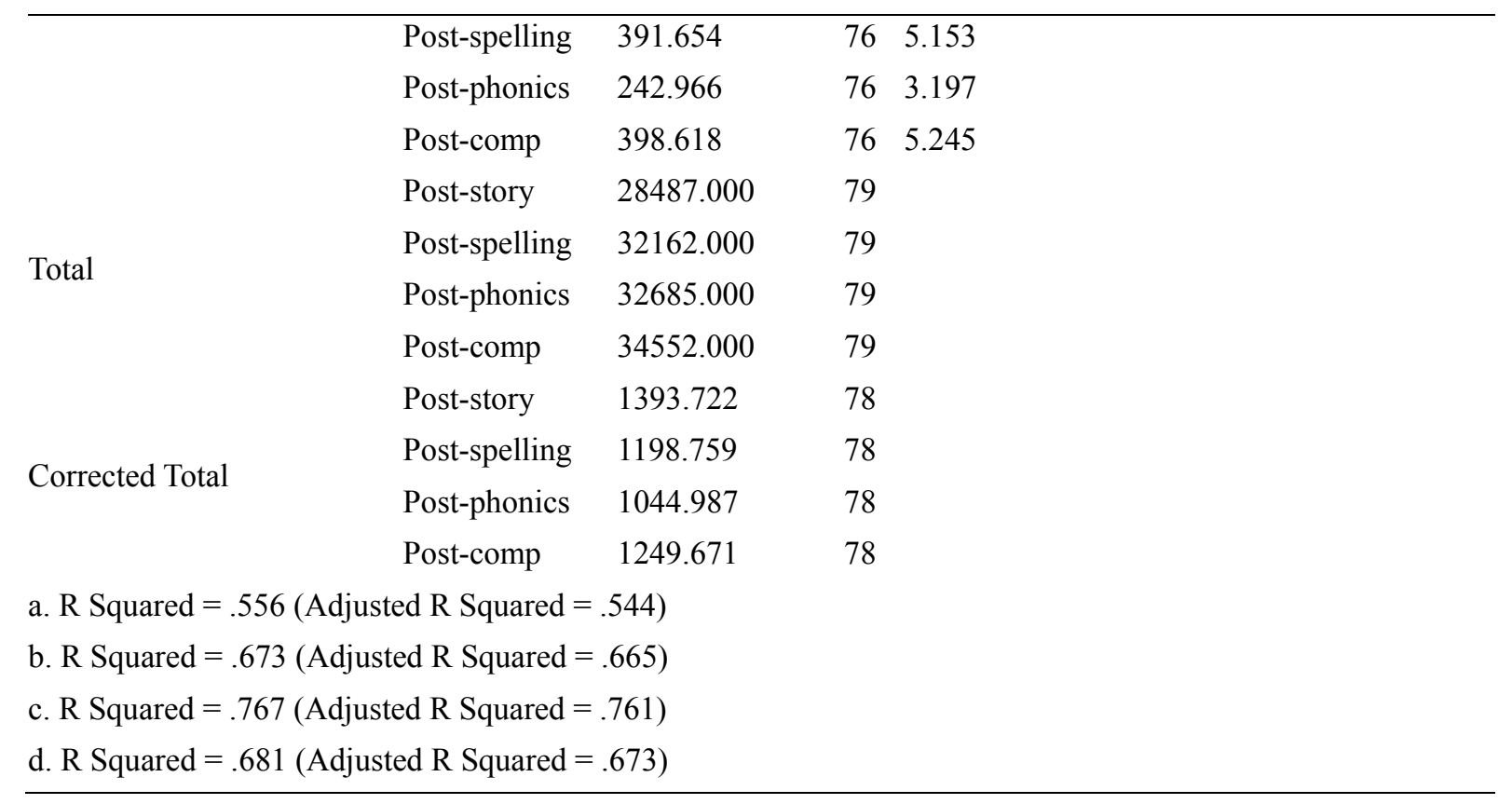

The results revealed that there were statistically significant differences between the two groups on the combined dependent variables, $F(4,73)=429.13, p=0.00$; Wilks' Lambda $=0.04 ; \eta 2=0.96$. When the results for the dependent variables were considered separately, there were differences at all levels. The results of the MANCOVA (as shown in table 2) show that there were significant differences between the mean scores of the two groups on post-reading test scores at the students' reading-based retelling skills, $\mathrm{F}(2,76)=47.51, \mathrm{p}=0.00$, partial eta squared $=0.56$. The partial eta squared value indicates that $56 \%$ of the variance in students' reading-based retelling skills is explained by the use of the talking story books (independent variable). The experimental group also outperformed the control group in the way they retold narratively upon hearing the read-aloud story; they depended very much on their auditory memory retention to retell the main events and ideas, which might also improve their reading-based speaking skill. From the researcher's daily observations of the control group, the traditional way in which the control group understood the story made them feel bored and less engaged to retell ; the mean performance of the experimental group (22.1) was higher than that of the control group (14.8).

The results of the MANCOVA (as shown in table 2) also show that there was a significant difference between the mean scores of the two groups on post-reading test scores at the students' understanding of talking-story-books, $\mathrm{F}(2,76)=81.13, \mathrm{p}=0.00$, partial eta squared $=.68$. The partial eta squared value indicates that $68 \%$ of the variance in students' understanding scores is explained by the use of the talking story books (independent variable). The experimental group did better than the control group in the true-false questions that checked particularly their understanding of the stories. This means that talking story books strengthened the participants' auditory memory to answer the questions while the control group had to go to the story many times to check for their answers.

In addition, Table 2 shows the results of the MANCOVA which proved that there was a significant difference between the mean scores of the two groups on post-reading test scores at the students' reading-based spelling skills, $F(2,76)=78.31, p=0.00$, partial eta squared $=.67$. The partial eta squared value indicates that $67 \%$ of the variance in students' reading-based spelling skills scores is explained by the use of the talking story books (independent variable).

Finally, the results of MANCOVA proved that there was a significant difference between the mean scores of the two groups on post-reading test scores at the students' reading-based phonics skills, $F(2,76)=125.34, p=0.00$, partial eta squared $=.77$. The partial eta squared value indicates that $77 \%$ of the variance in students' reading-based spelling skills scores is explained by the use of the talking story books (independent variable).

When the participants were requested to write a fitting conclusion or completion of about 3-5 lines to the read-aloud story, the experimental group did much better than the control group in that they depended on their read-aloud auditory memory to predict and visualize further events, while the control group depended on strings 
of sentences taken from the story itself which made their creative ability to write limited.

The results of the current research study reveal interesting and seminal results based on the performance of both the control group and the experimental group of the Saudi young EFL learners. These findings go in line with other previous studies such as Al-Mansour and Al-Shorman (2010), Stroh (2012), Saka (2015), and Zolfagharkhani and Kowsary (2013) in confirming the effectiveness of talking story books in enhancing EFL learners' different language skills. In the current study, the in-class implementation of the talking story books on the experimental group participants revealed considerable effects on the reading comprehension skills and sub-skills over the four weeks of the experimentation. The experimental group participants outperformed their control group counterparts in terms of the effects of talking story books on reading comprehension skills. The reading-based understanding of the experimental group participants was remarkably enhanced.

Thus, based on the results of the post-test, the implementation of talking story books in EFL classes for Saudi young learners produced positive effects on their other reading-based skills: understanding stories, phonics skills, spelling skills, and story retelling skills. Over the four-week period, the talking story books enhanced the learners' auditory memory; it became more retentive to retell a short story upon hearing it read aloud. The experimental group participants depended very much on their auditory memory to unlock the exercise questions and felt the class was more riveting and spellbinding than the traditional methods of teaching reading comprehension.

\section{Conclusion and Recommendations}

The implementation of talking story books in EFL classes for Saudi young learners is very much helpful and conducive. The effects of talking story books are enormous on reading comprehension skills and other language skills, which also proves that language skills can be best taught when integrated. Reading comprehension based on talking story books opens a wide door to optimally link speaking to listening and reading to writing, making all the language skills work in synergy to improve overshadowed microscopic skills.

The positive results of the research study puts forward a set of seminal recommendations for school curriculum designers and experts, future research, pedagogists, teaching methodologists, EFL teachers and parents to place a special focus on talking story books, read-aloud activities and audiobooks:

1) Talking story books are the key to pronunciation skills such as accent, stress, intonation, and rhythm. Therefore, a young learner should first listen to a talking story book several times to polish up their pronunciatory skills.

2) Talking story books help discover the EFL young learners' auditory memory in retaining ideas, sequencing events and retelling the whole story. Storing information into the young learner's memory through the auditory memory seems more engaging than through reading the story in its written form. It is highly recommended that young learners should not depend too much on the written form of reading materials.

3) It is highly recommended that talking story books should be incorporated in school curricula on a weekly basis or day-to-day basis.

\section{References}

Ahmed, A., \& Abouabdelkader, H. (Eds.) (2016). Teaching EFL Writing in the 21st Century Arab World: Realities and Challenges. London: Palgrave Macmillan. https://doi.org/10.1057/978-1-137-46726-3

Al-Mahrooqi, R., \& Roscoe, A. (Eds.) (2014). Focusing on EFL Reading: Theory and Practice. UK: Cambridge Scholars Publishing.

Al-Mansour, N., \& Al-Shorman, R. (2010). The effect of teacher's storytelling aloud on the reading comprehension of Saudi elementary stage students. Journal of King Saud University - Languages and Translation, 23, 69-76.

Al-Mansour, N., \& Al-Shorman, R. (2014). The Effect of an Extensive Reading Program on the Writing Performance of Saudi EFL University Students. International Journal of Linguistics, 6(2). https://doi.org/10.5296/ijl.v6i2.5551

Alna, O. (1999). The importance of oral storytelling in literacy development. The Ohio reading teacher, 31(1), $15-18$.

Amer, A. (1997). The effect of the teacher's storytelling aloud on the reading comprehension of EFL students. ELT Journal, 51(1), 43- 47. https://doi.org/10.1093/elt/51.1.43 
Baskin, C. (2016). Strong Helpers' Teachings, Second Edition: The Value of Indigenous Knowledges in the Helping Professions. Toronto: Canadian Scholars' Press.

Cohen, V., \& Cowen, J. (2009). Literacy for Children in an Information Age: Teaching Reading, Writing, and Thinking. Canada: Cengage Learning.

Collins, J., Hammond, M., \& Wellington, J. (2002). Teaching and Learning with Multimedia. London and New York: Routledge.

$\mathrm{Du}, \mathrm{Y}$. (2016). The Use of First and Second Language in Chinese University EFL Classrooms. China: Springer. https://doi.org/10.1007/978-981-10-1911-1

Elley, W. B. (1991). Acquiring literacy in a second language: the effect of book-based programs. Language learning, 41(3), 375-411. https://doi.org/10.1111/j.1467-1770.1991.tb00611.x

Ellis, B. F. (1997). Why tell stories? Storytelling Magazine, 9(1), 21-23.

Hall. G. (Ed). (2016). The Routledge Handbook of English Language Teaching. New York and London: Routledge.

Hamada, Y. (2017). Teaching EFL Learners Shadowing for Listening: Developing Learners' Bottom-up Skills. London and New York: Routledge.

Haven, K. (2000). USA: Super Simple Storytelling: A Can-do Guide for Every Classroom, Every Day: Libraries Unlimited.

Hillman, J. (1975). Reading aloud to children: a rationale. ERIC Document Reproduction Service NO. ED 172152.

Isbell, R., Sobol, J., Lindauer, L., \& Lawrence, A. (2004). The effects of storytelling and story reading on the oral language complexity and story comprehension of young children. Early Childhood Education Journal 32(3), 157-163. https://doi.org/10.1023/B:ECEJ.0000048967.94189.a3

Kaderavek, J., \& Justice, L. M. (2002). Shared storybook reading as an intervention context: practices and potential pitfalls. American Journal of Speech-Language Pathology, 11(4), 395-405. https://doi.org/10.1044/1058-0360(2002/043)

Kalmane, R. (2012). Improving Reading Comprehension with Online Text Visualization Tools. USA: Lulu Press.

Kirin, W. (2010). Effects of Extensive Reading on Students' Writing Ability in an EFL Class. The Journal of Asia TEFL, 7(1), 285-308.

Mallan, K. (1997). Storytelling in the school curriculum. Educational Practice and Theory, 19(1), 75-82. https://doi.org/10.7459/ept/19.1.09

Mart, Ç. (2012). Developing Speaking Skills through Reading. International Journal of English Linguistic, 2(6). https://doi.org/10.5539/ijel.v2n6p91

McCarthy, S., Nicastro, J., Spiros, I., \& Staley, K. (2001). Increasing recreational reading through the use of readalouds. ERIC Document Reproduction Service NO. ED453541.

McCormick, S. (1977). Should you read aloud to your children? Languages Arts, 54, 139-163.

Mermelstein, A. (2015). Improving EFL learners' writing through enhanced extensive reading. Reading in a Foreign Language, 27(2), 182-198.

Möller, C. (2015). Young L2 learners' narrative discourse. Germany: Books on Demand.

Muslim, I. (2014). Helping EFL Students Improve their Writing. International Journal of Humanities and Social Science, 4(2).

Queini, H., Bahous, R., Nabhani, M., (2008). Impact of read-aloud in the classroom: a case study. The Reading Matrix, 8(10), 139-159.

Saka, Z. (2015). The Effectiveness of Audiobooks on pronunciation Skills of EFL Learners at Different Proficiency levels. The Programme of Teaching English as a Foreign Language. İHSAN DOĞRAMACI BILLKENT UNIVERSITY ANKARA.

Soler, J., \& Openshaw, R. (2006). Literacy Crises and Reading Policies: Children Still Can't Read! London and New York: Routledge.

Trelease, J. (1994). The read-aloud handbook. Penguin group, New York. 
Vivas, E., 1996. Effects of story reading on language. Language learning, 46(2), 189-216. https://doi.org/10.1111/j.1467-1770.1996.tb01234.x

Warwick, E. (1992). How in the world do students read? Delaware: International Reading association.

Williamson, J. (1988). Improving reading comprehension: some current strategies. English Teaching Forum, 26(1), 7-9.

Wood, M., \& Salvetti, E. P. (2001). Project Story Boost: Read-alouds for students at risk. The Reading Teacher 55(1), 76-83.

Zaytoun, A. S. (1988). Different techniques for teaching listening comprehension. English Teaching Forum, 24(1), 46-49.

Zimmerman, L. (2010). ESL, EFL, and Bilingual Education: Exploring Historical, Sociocultural, Linguistic, and Instructional Foundations. United States of America: IAP

Zolfagharkhani, M., \& Kowsary, M. (2013). The Relationship between Reading Aloud Strategies and Comprehension among the Iranian EFL learners in Pre-Intermediate Levels. Studies in Literature and Language, 6(1), 74-77.

\section{Copyrights}

Copyright for this article is retained by the author(s), with first publication rights granted to the journal.

This is an open-access article distributed under the terms and conditions of the Creative Commons Attribution license (http://creativecommons.org/licenses/by/4.0/). 